\title{
Study on Policy and Standard System of LED Lighting Industry in EU
}

\author{
Qing Ding ${ }^{1, *}$, Xiuying Liang ${ }^{1}$, Haihong Chen ${ }^{1}$, Meng Liu ${ }^{1}$, Jie Yang ${ }^{1}$ \\ ${ }^{1}$ Resource and Environment Branch, China National Institute of Standardization, 100191, Beijing, China
}

\begin{abstract}
This paper introduces the policy measures, regulations and standard systems of the LED lighting industry in EU, and analyzes the role of the EU's policy measures in promoting the level of its LED lightning technologies and accelerating the industry development, as well as the positive significance of the EU's standards and regulations in standardizing and leading the promotion and application of LED lighting products, realization of economic and social benefits, amongst others. In this paper, it is suggested that China should further enlarge policy-based support for promotion and application of key LED lighting technologies and products, enrich and improve the standard system, strengthen the implementation of standards, and set up a benign feedback mechanism for evaluation of standards.
\end{abstract}

\section{Introduction}

Energy conserving, emission reduction and green development have been now the common focuses of countries across the globe under the context of global energy shortage. According to statistics, the global power consumption of lighting accounts for about $20 \%$ of the total power consumption, while that figure is about $14 \%$ in China. Therefore, energy consumption of lighting is always a key factor concerned at home and abroad. As a new green and energy-conserving lighting product, LED lighting is rated as the new generation of eco-friendly lighting source thanks to its unique features of low energy consumption, robust controllability, rich colors, and long service life, amongst others. In recent years, continuous and increasing efforts have been made to accelerate the R\&D, application and promotion of LED lighting products thanks to favorable industrial supporting policies and global practice of the energy-conserving and environmental protection concept. Statistics indicate that the scale of global LED lighting industry in 2017 reached up to USD 385.91 billion, up $13.3 \%$ year on year.

The EU has always played its leading role in lighting application and technology R\&D, featuring the emerging optical application industry that grows at a rate twice the global average growth rate. The EU is also advantageous in LED lighting industry. Technically, the EU is mainly engaged in production of high value-added products and gives full play to its advantages in $R \& D$ of application technologies and absorption of the latest technologies resorting to its state-of-the-art optical and lighting fixture design technologies, thus offering advanced solutions to LED lighting. With regard to energy-saving benefits, energy consumption of lighting accounts for $12 \%$ of daily energy consumption (excluding that of heating and water heaters) in the EU. Residents there have formed high awareness of energy conserving and government and environmental protection agencies have also cherished LED lighting products that save more energy and reduce harmful emissions, as a result of high electric energy cost and reliance on imported fuels.

Data by CSA Research indicate that the EU has become the largest overseas market of China's LED fixtures in recent years, and imports about $20 \%$ of China's total LED lighting products annually.

Therefore, the study on policy and supervision system, its application status and technical features of the LED lighting industry in the EU and relevant suggestions on cooperation will promote the cooperation between China and the EU on LED lighting policies, standards, technologies and market transformation, accelerate the green development of the LED lighting industry, and further boost the global energy conserving and emission reduction, as well as the tackling of climate change.

\section{Policy system for the LED lighting industry}

The EU has launched diverse robust supporting policies to maintain the leading position of its lighting industry in global competition: Lighting the Future Program in early stage that defined the mainstream position of LED lighting in the field of lighting; Lighting the City Program in middle stage that vigorously promoted the public lighting demonstration project with cities as the pilot; the latest Lighting the Public Program that subdivides functions of LED lighting to better satisfy the consumers' demands in all aspects.

\subsection{Rainbow Project}

*Corresponding author: dingqing@cnis.ac.cn 
In July, 2000, the EU launched its "Rainbow Project", set up the ECCR and passed its BRITE/EURAM-3 program that supports to promote the application of white-light LED. Six major companies (LSTM, CRHEA-CNRS, Epichem, Aixtron, Thomson-CSF and Philips) and two universities (Surrey and Aveiro) were entrusted for implementation of the Project. The "Rainbow Project" is the most complete development plan of LED lighting of the EU so far, and is aimed to achieve high efficiency and energy conserving by applying LED lighting instead of using materials harmful to the environment, thus obtaining lighting effect similar to that of natural light.

Lasting for 42 months, the "Rainbow Project" mainly involves the development of gallium nitride-based equipment and related manufacturing infrastructure for the purpose of promoting the growth of two major markets: high-brightness outdoor lighting, such as traffic lights, large outdoor display boards, and car lights; high-density optical disk storage, such as those for multimedia environment. The "Rainbow Project" is technically aimed to achieve the demonstration of photoelectric equipment, including LED prototype in the range of $400 \sim 590 \mathrm{~nm}$ and laser diode working at $400 \mathrm{~nm}$ wavelength.

In July, 2004, the follow-up solid-state lighting research project of "Rainbow Project" was officially launched in Europe. The project is funded by the National Science and Technology Center of Russia and implemented by the Laboratory of Semiconductor Optics at the National Academy of Sciences of Belarus (with the participation of Aixtron Company in western Germany). The goal of this three-year project is to improve the performance of white LED, and explore low-cost silicon as a substrate to replace the small and expensive substrates such as sapphire or silicon carbide used in traditional blue LED production.

\subsection{Lighting the City}

According to statistics of the EU, public lighting accounts for $60 \%$ of the energy consumption budget of European cities, while $70 \%$ of which may be saved by replacing with intelligent LED products. It is estimated that about 90 million traditional street lamps need to be replaced in Europe and $75 \%$ of them have been used for more than 25 years, bringing great potential in energy conservation. Therefore, pubic lighting is prioritized in promotion of intelligent lighting as it may witness the most obvious demonstration effect and is easily penetrated in early stage.

In 2011, the EU issued the Green Paper "Lighting the Future - Accelerating the Utilization of New Lighting Technology", and then started its pace to gradually implement some demonstration projects in some pilot cities to promote LED in public lighting. By 2013, remarkable milestone results were achieved for these pilot projects. The EU believed LED technology is already a mature lighting technology after assessing the cost of products during their whole life cycle. As energy-conservation effects have been continuously found during its use, the cost of non-networked LED street lamps used in cities can be recovered within 6 to
10 years.

In the meantime, the EU Energy Efficiency Guidelines required EU member states to renovate government office buildings to meet the minimum energy efficiency standards and encourage the use of energy management systems. It also required the governments to purchase only high-quality products with energy efficiency labels and ecological design. Home lighting users were encouraged to purchase LED products with quality assurance. The new EU energy efficiency label set new energy efficiency standards A+ and $\mathrm{A}++$ for bulbs and lamps (including LED bulbs and lamps). High standards and requirements have also been adopted for the governments' green procurement programs.

In specific LED projects, the EU encouraged energy service companies to bear the risks of lighting renovation projects, which may get corresponding economic benefits after the projects' designed energy-conserving goals are realized. In these pilot cities, LED lighting products were used for street lamps and other public places, with remarkable energy-conserving and emission reduction effects achieved.

\subsection{Lighting the Public}

To ensure that all the LED products in the market meet the EU's Eco-Design Requirements, the EU officially launched the "Lighting the Public Program" on April 1, 2014 to actively promote the innovation and cooperation in LED lighting with people as the core. In the Program, humanized high demand fields such as nursing for middle-aged and elderly people, medical care and education are defined as the key R\&D fields for LED lighting in the future, with light quality and humanized design as the core for development of new technologies. In the meantime, it is also the intention of the LED industry to have systematic and standardized product quality standards to enhance consumers' understanding and trust in LED products, or to establish a brand-new product quality standard system based on previous standards.

\subsection{Strategic Roadmap for Lighting of the EU in 2025}

In March 2016, the Lighting Europe released the Strategic Roadmap 2025, which showed the new vision of Lighting Europe for the development of the European lighting market in the next decade (2015-2025). The Strategic Roadmap 2025 aims at the policy contents of innovation, energy, environment and growth under EU policy framework, and puts forward two main development lines of "improving the quality of life" and "circular economy", and further increases the development contents of sustainable lighting and healthy lighting on the basis of energy-conserving in lighting, which mainly covers three development directions of popularization of LED lighting products, application of intelligent lighting systems and realization of human-centric lighting. Lighting system, better light quality, human-centralized and sustainable development 
are the driving forces for the growth of European lighting market. The main contents of the Strategic Roadmap 2025 are shown in Table 1.

The Lighting Europe believes that the annual sales of traditional electric light source products will continue to decline and the penetration rate of LED will increase year by year since 2016 . However, compared with the energy-conserving level contributed by preplacing incandescent lamps with LED, improving the light efficiency of LED products may not play a significant role in energy-conserving effect. Instead, the key is to improve the energy efficiency level of the whole lighting system.

The lighting industry in Europe plays a leading role in technological development throughout the world, but its current development vision is being driven by energy efficiency, with people's health and safety neglected or even becoming an accessory part of energy-conserving. As a matter of fact, most people spend $90 \%$ of their time in various buildings, with great dependence on and demand for artificial lighting environment. By 2020, among the 514 million people of the EU, those exceeding 50 years old will exceed $41 \%$, becoming the target of the lighting system. In other words, efforts shall be made to improve consumers' happiness and health by improving light quality indoor and outdoor. By setting the core development concept of "human-centric lighting", the European Commission and its member states support the lighting industry to maintain its position and influence in this field, promote the concept of EU creation and manufacturing, create an industrial environment for manufacturing and $R \& D$ in $E U$, increase employment opportunities, expand market demands, and formulate trade policies conducive to industrial development.

The implementation of the roadmap will actively promote the correlation between the lighting system and energy infrastructure, building management system and intelligent lighting system, rather than the correlation with individual products. It also helps to realize the goal of human-centric lighting through intelligent lighting system.

\section{Standard and Regulation Systems}

\subsection{Standard System}

The EU's standard system for LED lighting is very similar to IEC's standard system. The former's EN series for LED lighting products are mostly converted from IEC standard. EU standards are mostly determined by the game between large lighting enterprises (such as Philips and OSRAM) which have been working in IEC Standards Technical Committee

for a long time and have always occupied advantageous positions in traditional lighting fields in terms of standards, therefore, they have great influence on the formulation of IEC standards. As shown in Table 2, the EU's LED lighting standards and regulations cover standards for LED light source products, lamp products, driving power lamps, safety requirements, performance requirements, energy efficiency requirements, photobiological safety requirements, etc.

\subsection{Regulation System}

Internally, the EU also standardizes various markets through diverse regulations. Laws and regulations of the EU include such forms as regulations, directives, decisions, recommendations and advice. Directives define the basic requirements, which are mandatory technical regulations that are commonly jointly issued by the European Parliament and the European Council to all member States, such as ErP Directive, RoHS Directive and WEEE Directive related to LED lighting products, covering ecological design, energy efficiency, environmental protection and electromagnetic compatibility of LED lighting products.

\subsubsection{ErP Directive}

The EU ErP Directive is a mandatory directive executed by the following means: giving priority to adopting the EU's coordinative standards for product test in accordance with the technical requirements and indexes in the execution measures to determine whether corresponding indexes and technical requirements are satisfied or not.

With regard to eco-design, the Eco-design Requirements for Non-Directional Household Lamps ((EC) No. 244/2009) mainly specifies the requirements for eco-design of non-directional and directional household LED lamps in the market (including lamps sold for non-domestic use, but integrated into other products), covering energy efficiency requirements, production information requirements, conformity assessment requirements, and market supervision requirements, amongst others. Compliance with the Directive (EC) No. 244/2009 can be confirmed by the announcement of announcement institution of the EU and the third-party certification and testing institution, or self-declaration of the enterprise itself. (EC) No. $244 / 2009$ is included in the CE marking conformity assessment system, and only products conforming to relevant regulations and technical requirements can be pasted with CE marks. 
Table 1 Main Contents of the Strategic Roadmap 2025

\begin{tabular}{|c|c|}
\hline Task & ontents \\
\hline $\begin{array}{l}\text { Intelli } \\
\text { gent } \\
\text { Lighti } \\
\text { ng } \\
\text { Syste } \\
\text { m }\end{array}$ & $\begin{array}{l}\text { Develop intelligent lighting system } \\
\text { through intelligence, control, sensing and } \\
\text { dimming, aiming to: } \\
\text { maintain the leading position of the } \\
\text { lighting system; } \\
\text { provide users with better lighting via } \\
\text { LED intelligent lighting system; } \\
\text { include the lighting into building } \\
\text { management system and smart city } \\
\text { network via lighting design to } \\
\text { optimize the lighting quality. }\end{array}$ \\
\hline $\begin{array}{l}\text { Circul } \\
\text { ar } \\
\text { econo } \\
\text { my }\end{array}$ & $\begin{array}{l}\text { Further reduce the ecological footprint of } \\
\text { lighting industry: } \\
\text { Commission and establish strategic } \\
\text { partnerships with stakeholders to } \\
\text { determine the follow-up action steps } \\
\text { in the policy field; } \\
\text { Take renovation, remanufacturing, } \\
\text { reuse and redistribution as elements } \\
\text { of circular economy; } \\
\text { Extend the service life of LED } \\
\text { lighting system, and realize } \\
\text { maintainability, upgradeability, } \\
\text { maintainability, durability and } \\
\text { recycling. }\end{array}$ \\
\hline $\begin{array}{l}\text { human } \\
\text {-centri } \\
\mathrm{c} \\
\text { lightin } \\
\mathrm{g}\end{array}$ & $\begin{array}{l}\text { Become the driving force to light the } \\
\text { whole Europe: } \\
\text { improve users' understanding of } \\
\text { human-centric lighting; } \\
\text { shift from pure "efficiency think" to } \\
\text { "user interest think" to satisfy users' } \\
\text { personalized demands; } \\
\text { Cooperate with stakeholders to } \\
\text { implement human-centric lighting } \\
\text { for the benefit of European people, } \\
\text { society and industry. }\end{array}$ \\
\hline $\begin{array}{l}\text { LED } \\
\text { ificati } \\
\text { on }\end{array}$ & $\begin{array}{l}\text { Main activities since } 2017 \text { include: } \\
\text { - formulating "single lighting rules" } \\
\text { that replace } 3 \\
\text { according to the ENER } \\
\text { of Building Directive (EPBD). }\end{array}$ \\
\hline
\end{tabular}

In terms of environmental protection, the Restriction of the Use of Certain Hazardous Substances in Electrical and Electronic Equipment (RoHS, 2002/95/EC) and the Waste Electrical and Electronic Equipment Directive (WEEE, 2002/96/EC) specify the restriction of the use of hazardous substances and requirements for waste products respectively.

\subsubsection{EuP Directive}

In 2005, the European Parliament and the European Council officially published the Directive on Establishing a Framework for the Setting of Eco-design Requirements for Energy-related Products (EuP Directive). The Directive on Eco-design Requirements for Non-Directional Household Lamps ((EC)No. 244/2009) issued by the EU in 2019 stipulates that the EU will gradually ban the use of low-efficiency bulbs (traditional incandescent and halogen bulbs) from September 2009, and all non-directional lamps (bulbs) must comply with the minimum energy efficiency requirements. With the elimination of traditional lighting

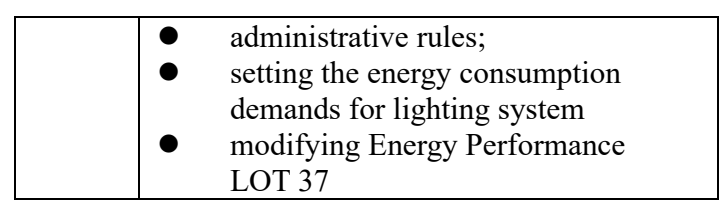

Table 2 Summary of the EU's LED

Lighting Standards and Regulation

\begin{tabular}{|c|c|}
\hline $\begin{array}{l}\text { Stand } \\
\text { Numb }\end{array}$ & Standard Title \\
\hline EN 62031 & $\begin{array}{l}\text { LED Modules for General Lighting } \\
\text { - Safety Specifications }\end{array}$ \\
\hline EN 6 & $\begin{array}{l}\text { Miscellaneous Lampholders - Par } \\
2-2: \quad \text { Particular requirements } \\
\text {-Connectors for LED-modules }\end{array}$ \\
\hline EN 61347-1 & $\begin{array}{l}\text { Lamp Controlgear - Part 1: Genera } \\
\text { and Safety Requirements }\end{array}$ \\
\hline $\begin{array}{l}\text { EN } \\
61347-2-13\end{array}$ & $\begin{array}{l}\text { Lamp Controlgear }- \text { Part 2-13 } \\
\text { Particular Requirements for DC or } \\
\text { AC Supplied Electronic } \\
\text { Controlgear for LED Modules }\end{array}$ \\
\hline EN & $\begin{array}{l}\text { Photobiological Safety of Lamps } \\
\text { and Lamp Systems }\end{array}$ \\
\hline EN & $\begin{array}{l}\text { Assessment of Lighting Equipment } \\
\text { Related to Human Exposure to } \\
\text { Electromagnetic Fields }\end{array}$ \\
\hline EN 6 & $\begin{array}{l}\text { Luminaires - Part 1: Genera } \\
\text { Requirements and Tests }\end{array}$ \\
\hline EN 6 & $\begin{array}{l}\text { Luminaires - Part 2: Particular } \\
\text { Requirements }\end{array}$ \\
\hline $\begin{array}{l}(\mathrm{EC}) \mathrm{Nc} \\
2009\end{array}$ & $\begin{array}{l}\text { Establishing A Framework for the } \\
\text { Setting of Eco-design Requirements } \\
\text { for Energy-related Products }\end{array}$ \\
\hline $\begin{array}{l}(\mathrm{EC} \\
200\end{array}$ & $\begin{array}{l}\text { Eco-design Requirements for } \\
\text { Non-Directional Household Lamps }\end{array}$ \\
\hline $\begin{array}{l}\text { (EU)No874/ } \\
2012\end{array}$ & $\begin{array}{l}\text { Energy Labeling of Electrica } \\
\text { Lamps and Luminaires }\end{array}$ \\
\hline $\begin{array}{l}\text { (EC)No95/2 } \\
002\end{array}$ & $\begin{array}{l}\text { Restriction of the Use of Certain } \\
\text { Hazardous Substances in Electrica } \\
\text { and Electronic Equipment (RoHS) }\end{array}$ \\
\hline $\begin{array}{l}(\mathrm{EC}) \mathrm{No} 95 / 2 \\
002\end{array}$ & $\begin{array}{l}\text { Waste Electrical and Electronic } \\
\text { Equipment (WEEE) Directive }\end{array}$ \\
\hline $\begin{array}{l}(\mathrm{EU}) \mathrm{No} 30 / 2 \\
014\end{array}$ & $\begin{array}{l}\text { EU Electromagnetic Compatibility } \\
\text { Directive }\end{array}$ \\
\hline
\end{tabular}

products, the common household lamps sold in EU market after 2016 will be mainly high-efficiency and energy-conserving compact fluorescent and LED lamps. In addition, the Directive also clearly stipulates performance indexes related to energy efficiency, such as rated life, optical communication maintenance rate, switching cycle times before scrapping, premature scrapping rate, starting time and color rendering index.

On July 12, 2012, the European Parliament and the European Council issued Directive (EU) 874/2012 on Energy Labeling of Electrical Lamps and Luminaires, which stipulates the energy efficiency labeling of incandescent lamps, fluorescent lamps, high-pressure gas discharge lamps, LED lamps and LED modules for general lighting. This Directive is not applicable to battery-powered lamps and LED modules with luminous flux less than 30 lumens. In the Directive, two types of energy efficiency labels are given: non-packaging printing (see Fig.1(a)) and packaging printing (see Fig. 1(b)) 


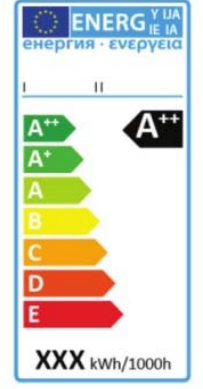

Fig 1(a) Non-packaging Label
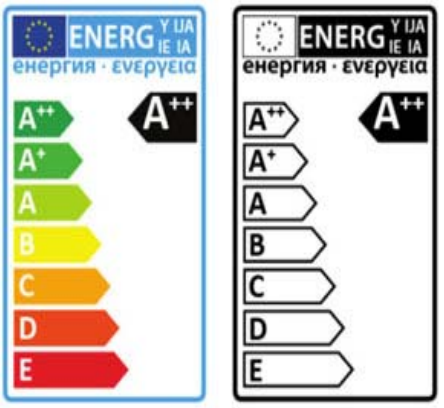

Fig.1(b) Packaging Label

This Directive also gives the style of lamp labels in sales place. Fig. 2(a) and Fig. 2(b) respectively show the energy efficiency labels of replaceable lamps with LED light sources and lamps with irreplaceable LED light sources.

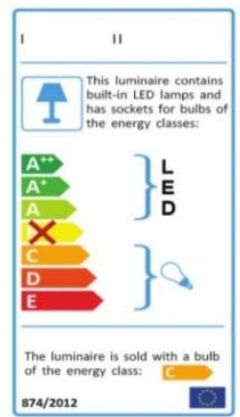

Fig.2(a) Energy Efficiency Label of Replaceable Lamps

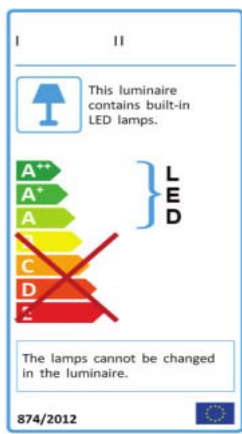

Fig.2(b) Energy Efficiency Label of Irreplaceable Lamps

\section{Summary and Enlightenment}

With regard to policy planning, the EU has put the LED lighting technologies in Europe to a world leading status and maintained the leading advantages of the lighting industry in global industry competitions by launching such policy measures as "Rainbow Plan", "Lighting the City Program", "Lighting the Public Program", and the Strategic Roadmap 2025. In the meantime, the EU has also defined the directions of LED lighting products, intelligent lighting products, human-centric lighting and circular economic by gradually subdividing the functions of LED lighting products to better satisfy the demands of consumers in all aspects.

In the next step, competent authorities in China are suggested to increase investment in $R \& D$ of the third-generation LED devices represented by $\mathrm{SiC}$ and $\mathrm{GaN}$, as well as ultra-high light efficiency and high-quality full-spectrum LED chips and devices, thus consolidating China's leading position in the third-generation LED materials, middle and upstream technologies, and other aspects. In the meantime, it is also suggested to take incentive policies and measures to increase the promotion and popularization of LED lighting products, such as incorporation of LED lighting products into the green lighting engineering system, preparation of catalogue of financial subsidies for efficient lighting, list of government procurement of energy-conserving products, catalogue of prioritized procurement, and formulation of bulk procurement plan.

As for standards and regulations, the $\mathrm{EU}$ has always occupied certain advantages in standards and regulations thanks to the dominated role of Philips, OSRAM and other large lighting enterprises in formulation of IEC standards. Perfect LED lighting standards and labeling rules, and effective implementation of directives, decisions and other regulations lay a solid foundation for a strict and well-order LED lighting market in the EU.

To date, China has initially established a lighting product standard system that covers basic terms, performance, safety, test methods, energy efficiency and other standards. Among them, safety and electromagnetic compatibility standards cover LED lighting products accessories such as LED modules and control devices, as well as self-ballasted LED lamps, LED downlights, LED lights for road lighting and other major LED light sources and products. Energy efficiency standards cover four types of indoor lighting products, such as street lamps, tunnel lamps and LED downlights. In the next step, China is suggested to strengthen the research on standardization of LED lighting, expand the product portfolios covered by the standards, enrich the categories and contents of LED lighting standards, and further improve the standard system. The key directions include blue light hazards, stroboscopic and other light environmental health problems, evaluation index system of high-efficiency and high-quality green lighting products covering energy, resources, environment and quality attributes, and operation optimization, intelligent control and performance evaluation of lighting systems. On the other hand, it is also suggested to strengthen the publicity and implementation of LED lighting standards, so that LED standards can become the production norms 
and R\&D guidance of enterprises and basis for consumers to purchase green and efficient lighting products. Furthermore, China should strengthen the crackdown and punishment of counterfeit and shoddy LED lighting products in production and circulation, false standards of energy efficiency, non-standard production, and violation of standard requirements, establish a credit evaluation system for enterprises and merchants, and guide and encourage relevant parties to strengthen self-management. Last but not the least, China should evaluate the implementation effect of LED standards, measure the rationality of the standard indexes as well as social and economic benefits in a timely and effective manner, and immediately give feedback on evaluation results as a reference for revision of relevant standards.

\section{Acknowledgement}

Supported by National Key Research and Development Plan Program "Research on the key technical standards of Modern Coal chemical industry" (2018YFF0213803).

\section{References}

1. China Solid State Lighting Alliance. Blue Book of China's Semiconductor Lighting Industry Development of 2017[R].

2. Global Environment Protection Research. Report on energy conservation lighting of Europe Union 2014[R].

3. China Solid State Lighting Alliance. Analysis and Enlightenment of EU LED Lighting Energy-saving Industry Policy of 2018[R].

4. Zhang Junbin. EU Regulation on Energy Labeling of Electric Lamps and Luminaries. China Light and Lighting, 2013(6).

5. TONG Shenghua. The requirement and Comparative Analysis of LED Energy Efficiency in U.S.A and EU. Energy Conservation and Environmental Protection, 2011(1). 